\title{
Nutrient status of rangeland in upper Mustang
}

\author{
M. Maharjan', K. D Awasthi' ${ }^{2}$ K. R Pande ${ }^{3}$ and N. Thapa ${ }^{4}$
}

The study aimed at assessing the nutrient status of rangeland in upper Mustang. The assessment is necessary to know about the soil quality or productivity of soil of rangeland. Livestock rearing is one of the main occupations in upper Mustang but nowadays due to lack of palatable species for livestock, people are leaving the occupation which is directly affecting their livelihood status. Therefore this research was carried out to find out if the soil nutrient is the reason behind the lack of availability of palatable species in the rangeland. For soil sampling, north and south aspects were taken. In case of altitude, $3850 \mathrm{~m}, 3650 \mathrm{~m}$ and $3450 \mathrm{~m}$ were taken. Soil samples were taken from soil profile up to $60 \mathrm{~cm}$ depth at interval of $20 \mathrm{~cm}$. Available phosphorus and available potassium were found to be high at north aspect but total nitrogen was found to be high at south aspect. Both total nitrogen and available phosphorus were found to be high at $3650 \mathrm{~m}$. Available potassium was gradually decreased with increasing altitude. Total nitrogen, available potassium and available phosphorus were gradually decreased with increasing soil depth. Nutrient status was high at top soil $(0-20 \mathrm{~cm})$. The soil nutrient (Nitrogen, Phosphorus, Potassium) status was found to be good in the study area. Further research on biophysical and ecological aspect of Rangeland in Upper Mustang is necessary to manage it properly.

Key words: Nutrient, Nitrogen, Phosphorus, Potassium, rangeland, upper Mustang

$\mathrm{R}$ angelands of upper Mustang are major source to sustain livestock as well as people's livelihood as they are rich in medicinal and aromatic plants and TransHimalayan biodiversity. They are also sources of other natural resources, tourism, carbon sink, valuable cultural landscape, place for recreation and aesthetic value, and beautiful scenery. Much of the Mustang landscape is dominated by pastures but the prevailing harsh climatic condition does not permit to grow sufficient grasses in these lands (Kunwar, 2003). Agricultural production in these areas is very limited due to scarcity of water, lack of proper irrigation, low temperature for longer periods and low rainfall (Thakali, 1994).

Very limited research work carried out in the field of soil properties/quality/ nutrient in rangeland especially in upper Mustang. The study will be beneficial to find out the status of soil nutrient which is beneficial for improving livelihood of local people through proper management of rangeland.
The objective of the study was to find out the status of nutrient of rangeland in upper Mustang.

\section{Materials and methods}

\section{Study Area}

Upper Mustang, particularly Lo-manthang lies in the northern part of Mustang District approximately at $83^{\circ} 45^{\prime}$ to $84^{\circ} 15^{\prime} \mathrm{E}$ and $29^{\circ} 04^{\prime}$ to $29^{\circ} 18^{\prime} \mathrm{N}$ (Fig. 1). The climate of the area can be characterized as cold desert, desiccated by strong winds and high solar radiation. The total area of Lo-mangthang VDC is 282.25 sq. $\mathrm{km}$. with total population of 800 (MOP, 2009). The altitude range of Lo-manthang VDC ranges from $3200 \mathrm{~m}$ to $6500 \mathrm{~m}$.

\section{Sampling method}

The stratified sampling method was adopted for the study. The starting point was selected randomly and considered as centre point. After selecting the center point, two plots each having $50 \mathrm{~m}$ perpendicular distance from center line were

\footnotetext{
${ }_{1}$ Tribhuwan University, Institute of Forestry, Hetauda, Nepal, Email: menuka48maharjan@gmail.com

2 Tribhuwan University, Institute of Forestry, Pokhara, Nepal

Tribhuwan University, Institute of Agriculture and Animal Science, Rampur, Nepal

4 Annapurna Conservation Area Project, Pokhara, Nepal
} 


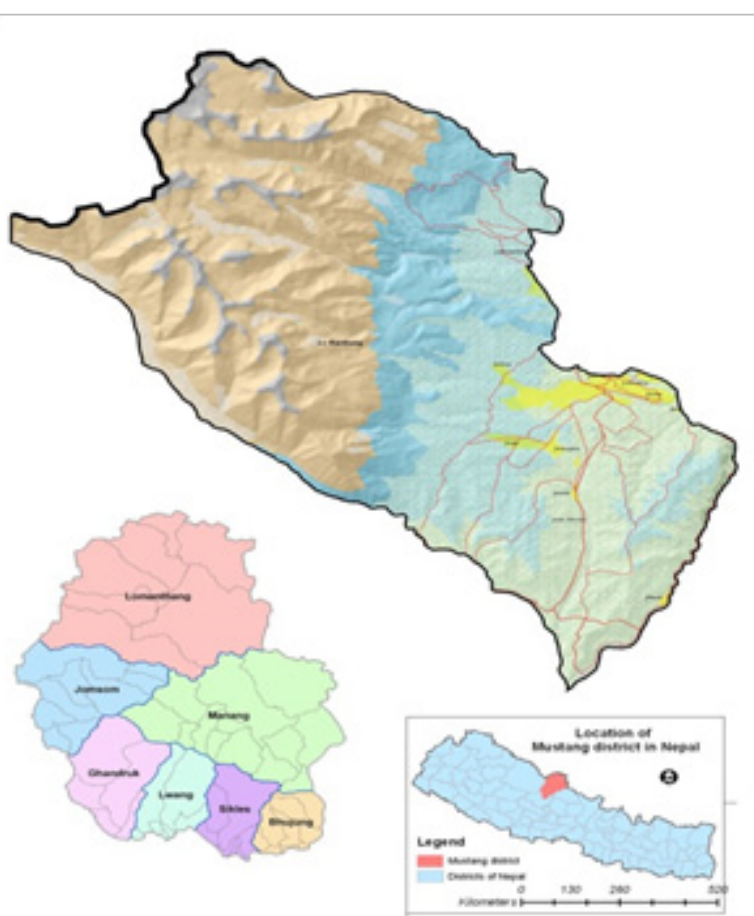

Fig. 1: Study area (Source: MOP, 2009)

fixed. For soil sampling, north and south aspects were taken. Soil samples were collected from three different altitudes $(3850 \mathrm{~m}, 3650 \mathrm{~m}$ and $3450 \mathrm{~m}$ ). Three replication of soil samples were taken from each strata for computing nutrient as well as carbon stock measurement.

For nutrient profile, soil was dug at the centre part of the plot up to $60 \mathrm{~cm}$ depth. Soil samples at different depths $(0-20 \mathrm{~cm}, 20-40 \mathrm{~cm}, 40-60$ $\mathrm{cm})$ were collected. A core ring sampler $(4.8 \mathrm{~cm}$ diameter and $10 \mathrm{~cm}$ long) was used for estimation of bulk density.

\section{Soil properties under study with methods of measurement}

Soils are generally categorized into three categories. They are i) acidic soils (with $\mathrm{pH}$ values less than 6.5), ii) nearly neutral soils (with $\mathrm{pH}$ value 6.5-7.5), and alkaline soils (with $\mathrm{pH}$ values more than 7.5) (NARC, 1993). Different methods are used to determine the soil properties (Table 1). The soil texture was measured using Hydrometer Method whereas the soil chemical properties: the $\mathrm{pH}$, the total nitrogen ( $\mathrm{TN})$, the available phosphorus (AP) and the available potassium (AK) were measured using the Glass Calomel $\mathrm{pH}$ Meter, Kjeldahl Method and Olsen's and Somers Method (1982) and the Frame Photometer Method respectively. The soil samples were analyzed at the Regional Soil Laboratory, situated at Lumle, Kaski District, to assess the status of the major physico-chemical properties. The textures of the soil were determined on the basis of the relative distribution of sand, silt and clay in the sample.

Table 1: Soil properties under study with their methods of measurement

\begin{tabular}{ll}
\hline Soil properties & Methods \\
\hline $\begin{array}{l}\text { Physical } \\
\text { Texture } \\
\text { Chemical } \\
\text { pH }\end{array}$ & Hydrometer method \\
Total Nitrogen(TN) & $\begin{array}{l}\text { Glass calomel pH meter } \\
\text { Kjeldahl method (Bremner } \\
\text { and Mulvaney, 1986) }\end{array}$ \\
$\begin{array}{ll}\text { Available Phosphorus } \\
\text { (AP) }\end{array}$ & $\begin{array}{l}\text { Olsen's and Somers } \\
\text { method (1982) }\end{array}$ \\
$\begin{array}{l}\text { Available Potassium } \\
\text { (AK) }\end{array}$ & Flame Photometer method \\
\hline
\end{tabular}

\section{Interpretation of different soil properties}

Table 2 shows that $\mathrm{pH}$ range in soil according to $\mathrm{pH}$ value. If $\mathrm{pH}$ value is less than 4.5 then soil is strongly acidic. It's value is between 4.5 to 5.5 , soil considers as moderately acidic. If $\mathrm{pH}$ value is between 5.5 and 6.5 then soil is weakly acidic in nature. If the value is between 6.5 and 7.5 then soil is nearly neutral. If the value is greater than 7.5 , soil is alkaline in nature.

Table 2: Interpretation for soil pH

\begin{tabular}{ll}
\hline $\mathbf{p H}$ & Range \\
\hline$<4.5$ & Strongly acidic \\
$4.5-5.5$ & Moderately acidic \\
$5.5-6.5$ & Weakly Acidic \\
$6.5-7.5$ & Nearly Neutral \\
$>7.5$ & Alkaline \\
\hline
\end{tabular}

Table 3 shows that level of different nutrients (TN, AP and AK) in soil. If TN (\%) is less than 0.1 , soil has low level of TN whereas if it is higher than 0.2 then soil has high level of TN. If $\mathrm{AP}(\mathrm{kg} /$ ha) is less than 31, soil has low level of AP and if it is more than 55 then soil has high amount of AP. Regarding AK ( $\mathrm{kg} / \mathrm{ha})$, if the range is less than 110 then soil has low level of AK and if it is more than 280 then soil has high amount of AK. 
Table 3: Interpretation table for soil fertility

\begin{tabular}{llllll}
\hline \multicolumn{2}{r}{ TN (\%) } & \multicolumn{2}{c}{ AP (kg/ha) } & \multicolumn{2}{c}{ AK (kg/ha) } \\
\hline Range & Level & Range Level & Range & Level \\
$<0.1$ & Low & $<31$ & Low & 110 & Low \\
$0.1-0.2$ & Medium & $31-55$ & Medium & $110-280$ & Medium \\
$>0.2$ & High & $>55$ & High & $>280$ & High \\
\hline
\end{tabular}

Source: NARC, 1993

The texture of the soil was determined from the relative distribution of sand, silt and clay in the sample.

\section{Statistical analysis}

Data analysis was carried out using SPSS and Microsoft Excel. Descriptive statistics used to produce tables while inferential statistics also used to test the relationships between different variables under study. One-way ANOVA was carried out to test the variation of different properties of soils with respect to different factors under study. Multiple comparisons of means were carried out using $\operatorname{LSD}_{0.05}$.

\section{Results and discussion}

\section{Physico-chemical properties of soil}

$\mathrm{pH}$ (8.7) was high at $\operatorname{North}(\mathrm{N}) / 3650 \mathrm{~m}$ and South $(\mathrm{S}) / 3450 \mathrm{~m}$ followed by $\mathrm{S} / 3850 \mathrm{~m}$ and $\mathrm{S} / 3650 \mathrm{~m}(8.6)$ and N/3450 $\mathrm{m}(8.5), \mathrm{N} / 3850 \mathrm{~m}$ (8.4) as shown in table 4 . The soil of the study area was basic in nature. Due to low rainfall the soil of the arid region is basic in nature.

The dominant texture classes were sandy loam and loamy sand. Loamy sand texture class was found at N/3850 $\mathrm{m}$ followed by sandy loam text class at $\mathrm{S} / 3850 \mathrm{~m}$. Similarly, sandy loam texture class was found at N/3650 m, N/3450 m and loamy sand texture class at $\mathrm{S} / 3650 \mathrm{~m}, \mathrm{~S} / 3450 \mathrm{~m}$.

Status of nutrients at different aspects, altitudes and soil depths

\section{Total Nitrogen}

Total nitrogen was higher at south aspect $(0.20 \%)$ than north aspect $(0.19 \%)$ as shown in table 5 . Due to high clay content and biomass, high nitrogen stock was found in the southern aspect.

Table 5: Total nitrogen (\%) at different aspects

\begin{tabular}{lrrrrr}
\hline Aspect & Mean & Max. & Min. & Range & $\begin{array}{c}\text { Standard } \\
\text { error }\end{array}$ \\
\hline North & 0.19 & 0.23 & 0.16 & 0.07 & 0.008 \\
South & 0.20 & 0.34 & 0.14 & 0.20 & 0.021 \\
Mean & 0.19 & & & & \\
\hline
\end{tabular}

TN was high at $3650 \mathrm{~m}(0.22 \%)$ followed by $0.19 \%$ at $3450 \mathrm{~m}$ and $0.17 \%$ at $3850 \mathrm{~m}$ as shown in table 6 . There was fluctuation in $\mathrm{TN}$ at different altitude. Due to presence of deep rooted vegetation, TN was high at $3650 \mathrm{~m}$ altitude.

Table 6: Total nitrogen (\%) at different altitudes

\begin{tabular}{crrrrr}
\hline $\begin{array}{c}\text { Altitude } \\
(\mathbf{m})\end{array}$ & Mean & Max. & Min. & Range & $\begin{array}{c}\text { Standard } \\
\text { error }\end{array}$ \\
\hline 3450 & 0.19 & 0.23 & 0.16 & 0.07 & 0.01 \\
3650 & 0.22 & 0.34 & 0.16 & 0.18 & 0.02 \\
3850 & 0.17 & 0.23 & 0.14 & 0.09 & 0.01 \\
\hline Mean & 0.19 & & & & \\
\hline
\end{tabular}

Table 4: Physico-chemical properties of soil at different aspect and altitudes

\begin{tabular}{|c|c|c|c|c|c|}
\hline \multirow{2}{*}{$\begin{array}{l}\text { Aspect/ } \\
\text { Altitude }\end{array}$} & \multirow{2}{*}{ pH } & \multicolumn{3}{|c|}{ Particle size distribution (\%) } & \multirow{2}{*}{$\mathbf{T C}^{*}$} \\
\hline & & Sand & Silt & Clay & \\
\hline & Mean \pm SE & Mean \pm SE & Mean \pm SE & Mean \pm SE & \\
\hline $\mathrm{N}^{* * / 3850 \mathrm{~m}}$ & $8.4 \pm 0.1$ & $77.53 \pm 2.5$ & $20.99 \pm 2.61$ & $1.47 \pm 0.95$ & LS \\
\hline $\mathrm{S}^{* * *} / 3850 \mathrm{~m}$ & $8.6 \pm 0.06$ & $71.32 \pm 0.29$ & $27.22 \pm 0.29$ & $1.46 \pm 0.0$ & SL \\
\hline $\mathrm{N}^{* * / 3650 \mathrm{~m}}$ & $8.7 \pm 0.05$ & $71.65 \pm 0.48$ & $27.05 \pm 0.53$ & $1.3 \pm 0.98$ & SL \\
\hline $\mathrm{S} * * * / 3650 \mathrm{~m}$ & $8.6 \pm 0.05$ & $73.76 \pm 0.48$ & $24.39 \pm 1.13$ & $1.85 \pm 0.72$ & LS \\
\hline $\mathrm{N}^{* * / 3450 \mathrm{~m}}$ & $8.5 \pm 0.88$ & $70.65 \pm 0.86$ & $27.78 \pm 0.77$ & $1.57 \pm 0.11$ & SL \\
\hline $\mathrm{S} * * * / 3450 \mathrm{~m}$ & $8.7 \pm 0.88$ & $74.43 \pm 1.63$ & $4.33 \pm 1.57$ & $1.24 \pm 0.72$ & LS \\
\hline
\end{tabular}

* $\mathrm{TC}=$ Textural class; $\mathrm{LS}=$ Loamy sand; $\mathrm{SL}=\mathrm{Sandy}$ loam, $* * \mathrm{~N}=$ North, $* * * \mathrm{~S}=$ South 
Total nitrogen was high at $0-20 \mathrm{~cm}(0.23 \%)$ followed by $0.20 \%$ at $20-40 \mathrm{~cm}$ and $0.16 \%$ at $40-60 \mathrm{~cm}$ soil depth as shown in table 7 . TN was gradually decreased with increasing soil depth. Vegetations present in the top soil were the main cause of this result.

Table 7: Total nitrogen (\%) at different soil depths

\begin{tabular}{lrrrrr}
\hline $\begin{array}{c}\text { Soil } \\
\text { Depth }\end{array}$ & Mean & Max. & Min. & Range & $\begin{array}{c}\text { Standard } \\
\text { error }\end{array}$ \\
\hline $0-20 \mathrm{~cm}$ & 0.23 & 0.34 & 0.19 & 0.15 & 0.02 \\
$20-40 \mathrm{~cm}$ & 0.20 & 0.28 & 0.16 & 0.12 & 0.02 \\
$40-60 \mathrm{~cm}$ & 0.16 & 0.19 & 0.14 & 0.05 & 0.01 \\
\hline Mean & 0.20 & & & & \\
\hline
\end{tabular}

One way ANOVA test revealed that $\mathrm{TN}$ was significantly different at different soil depth ( $p$ value $=0.04) . \mathrm{LSD}_{0.05}$ test showed that $\mathrm{TN}$ was significantly different between $0-20$ and 40-60 $\mathrm{cm}$ soil depth but no significant different was found with other soil depth as shown in table 8 .

Total nitrogen in the soil is solicited because the nitrogen in the soils occurs in several forms band it takes into account all the nitrogen in organic and inorganic forms. Some scientists argue that TN does not give good indication of soil fertility because only a small portion of TN is available to plants. About 2 to $3 \%$ of TN is in the inorganic form, mostly ammonium $\left(\mathrm{NH}_{4+}\right)$ and Nitrate $\left(\mathrm{NO}_{3}\right)$ which are only available to the plants (Bandel et al., 2000). Others present different views that organic and inorganic forms of nitrogen are always interchangeable and it would be better to consider the total nitrogen to investigate soil quality. Determination of Nitrate $\left(\mathrm{NO}_{3}\right)$ and Ammonium $\left(\mathrm{NH}_{4+}\right)$ would not give an overall picture of the fertility, but give a snapshot of the $\mathrm{N}$ availability not only for plants but also, for micro-organisms in the soil (Truelsen and Lundsby, 2001).

\section{Available Phosphorus}

Available phosphorus was high at north aspect $(71.86 \mathrm{~kg} / \mathrm{ha})$ followed by south aspect $(60.01$ $\mathrm{kg} / \mathrm{ha}$ ) as shown in table 9 . This table showed that AP was found higher at north aspect than south aspect.

Table 9: Available phosphorus (kg/ha) at different aspects

\begin{tabular}{lrrrrr}
\hline Aspect & Mean & Max. & Min. & Range & $\begin{array}{c}\text { Standard } \\
\text { error }\end{array}$ \\
\hline North & 71.86 & 93.30 & 46.70 & 46.60 & 5.72 \\
South & 60.01 & 86.70 & 23.30 & 63.40 & 7.18 \\
Mean & 65.93 & & & & \\
\hline
\end{tabular}

AP was varied at different altitude found high at $3650 \mathrm{~m}(77.78 \mathrm{~kg} / \mathrm{ha})$ followed by $69.46 \mathrm{~kg} / \mathrm{ha}$ at $3850 \mathrm{~m}$ and $50.55 \mathrm{~kg} / \mathrm{ha}$ at $3450 \mathrm{~m}$. Both TN and AP were found high at $3650 \mathrm{~m}$ as shown in table 10. High clay content at this altitude caused to show high TN and AP.

Table 10: Available phosphorus (kg/ha) at different altitudes

\begin{tabular}{lccccc}
\hline $\begin{array}{c}\text { Altitude } \\
(\mathbf{m})\end{array}$ & Mean & Min. & Max. & Range & $\begin{array}{c}\text { Standard } \\
\text { error }\end{array}$ \\
\hline 3450 & 50.55 & 23.30 & 93.30 & 70.00 & 9.86 \\
3650 & 77.78 & 66.70 & 90.00 & 23.30 & 3.82 \\
3850 & 69.47 & 50.00 & 86.70 & 36.70 & 5.80 \\
\hline Mean & 65.93 & & & & \\
\hline
\end{tabular}

One way ANOVA test revealed that AP was significantly different at different altitude $(\mathrm{p}$ value $=0.04) . \mathrm{LSD}_{0.05}$ test showed that $\mathrm{AP}$ was significantly different between $3450 \mathrm{~m}$ and 3650 $\mathrm{m}$ altitude where no significance difference found with other altitude $(\mathrm{p} \leq 0.05)$ as shown in table 11 .

Table 8: $\mathrm{LSD}_{0.05}$ for Total nitrogen (\%) at different soil depths

\begin{tabular}{llrrr}
\hline \multirow{2}{*}{ Factors } & Paris compared $(\mathbf{c m})$ & Mean difference & Standard error & \multicolumn{1}{c}{ Significance } \\
\hline TN & $0-20$ and $20-40$ & 0.33 & 0.24 & 1.85 \\
& $0-20$ and 40-60 & $0.68^{*}$ & 0.24 & 0.01 \\
& $20-40$ and 40-60 & 0.35 & 0.24 & 0.17 \\
\hline
\end{tabular}

* denotes the mean difference at $\mathrm{p} \leq 0.05$ 
Table 11: $\mathrm{LSD}_{0.05}$ for Available phosphorus (kg/ha) at different altitudes

\begin{tabular}{llccc}
\hline Factors & $\begin{array}{c}\text { Paris } \\
\text { compared }\end{array}$ & $\begin{array}{c}\text { Mean } \\
\text { difference }\end{array}$ & $\begin{array}{c}\text { Standard } \\
\text { error }\end{array}$ & Significance \\
\hline AP & $\begin{array}{l}3450 \text { and } \\
3650 \mathrm{~m}\end{array}$ & $-27.23^{*}$ & 9.85 & 0.01 \\
& & & \\
3450 and & -18.92 & 9.85 & 0.07 \\
$3850 \mathrm{~m}$ & & & \\
& 3650 and & 8.32 & 9.85 & 0.42 \\
$3850 \mathrm{~m}$ & & & \\
\hline
\end{tabular}

*denotes the mean difference at $\mathrm{p} \leq 0.05$

AP was gradually decreased with increasing soil depth. AP was found $75 \mathrm{~kg} / \mathrm{ha}$ at $0-20 \mathrm{~cm}$ followed by $65.01 \mathrm{~kg} / \mathrm{ha}$ at $20-40 \mathrm{~cm}$ and 57.78 $\mathrm{kg} / \mathrm{ha}$ at $40-60 \mathrm{~cm}$ soil depth as shown in table 12.

Awasthi (2004) reported that nutrient stock was found high at top soil which was found true in this study also where AP was high at $0-20 \mathrm{~cm}$ soil depth similarly AK and TN was also found high at the same soil depth.

Table 12: Available phosphorus (kg/ha) at different soil depths

\begin{tabular}{lccccc}
\hline $\begin{array}{c}\text { Soil } \\
\text { Depth }\end{array}$ & Mean & Max. & Min. & Range & $\begin{array}{c}\text { Standard } \\
\text { error }\end{array}$ \\
\hline $0-20 \mathrm{~cm}$ & 75.00 & 43.30 & 93.30 & 50.00 & 7.44 \\
$20-40 \mathrm{~cm}$ & 65.01 & 36.70 & 86.70 & 50.00 & 8.20 \\
$40-60 \mathrm{~cm}$ & 57.78 & 23.30 & 80.00 & 56.70 & 8.42 \\
\hline Mean & 65.93 & & & & \\
\hline
\end{tabular}

\section{Available Potassium}

Available Potassium was high at north aspect $(742.90 \mathrm{~kg} / \mathrm{ha})$ followed by south aspect $(531.37$ $\mathrm{kg} / \mathrm{ha}$ ) as shown in table 13. This result showed that AK status was quite good in the study according to table 13 .

Table 13: Available Potassium (kg/ha) at different aspects

\begin{tabular}{lcccccc}
\hline Aspect & Mean & Max. & Min. & Range & $\begin{array}{c}\text { Standard } \\
\text { error }\end{array}$ \\
\hline North & 742.90 & 266.70 & 1643.00 & 1376.30 & 147.93 \\
South & 531.37 & 283.30 & 1083.00 & 799.70 & 102.91 \\
Mean & 637.13 & & & & \\
\hline
\end{tabular}

AK was gradually decreased with increasing altitude. AK was high at $3450 \mathrm{~m}(753.22 \mathrm{~kg} / \mathrm{ha})$ altitude followed by $666.62 \mathrm{~kg} / \mathrm{ha}$ at $3650 \mathrm{~m}$ and
$491.57 \mathrm{~kg} / \mathrm{ha}$ at $3450 \mathrm{~m}$ as shown in table 14 . From table 14 it was concluded that AK status was good at all altitudes.

Table 14: Available potassium (kg/ha) at different altitudes

\begin{tabular}{ccccccc}
\hline $\begin{array}{c}\text { Altitude } \\
(\mathbf{m})\end{array}$ & Mean & Min. & Max. & Range & $\begin{array}{c}\text { Standard } \\
\text { error }\end{array}$ \\
\hline 3450 & 753.22 & 283.30 & 1643.00 & 1359.70 & 218.95 \\
3650 & 666.62 & 283.30 & 1083.00 & 799.70 & 134.15 \\
3850 & 491.57 & 266.70 & 1003.00 & 736.30 & 107.71 \\
\hline Mean & 637.13 & & & & \\
\hline
\end{tabular}

AK was gradually decreased with increasing soil depth. AK was high at 0-20 cm $(1052.50 \mathrm{~kg} /$ ha) followed by $20-40 \mathrm{~cm}(528.90 \mathrm{~kg} / \mathrm{ha})$ and $40-60 \mathrm{~cm}(330 \mathrm{~kg} / \mathrm{ha})$ soil depth as shown in table 15. The decreasing trend of AK was quite high according to depth of the soil but AK status was good at different soil according to table 15.

Table 15: Available potassium (kg/ha) at different soil depths

\begin{tabular}{lrrrrr}
\hline $\begin{array}{c}\text { Soil } \\
\text { Depth }\end{array}$ & Mean & Max. & Min. & Range & $\begin{array}{c}\text { Standard } \\
\text { error }\end{array}$ \\
\hline $0-20 \mathrm{~cm}$ & 1052.50 & 503.00 & 1643.00 & 1140.00 & 147.69 \\
$20-40 \mathrm{~cm}$ & 528.90 & 360.00 & 870.00 & 510.00 & 77.58 \\
$40-60 \mathrm{~cm}$ & 330.00 & 266.70 & 486.70 & 220.00 & 33.13 \\
\hline Mean & 637.13 & & & & \\
\hline
\end{tabular}

One way ANOVA revealed that AK was significantly different at different soil depth ( $\mathrm{p}$ value $=0.00$ ). $\mathrm{LSD}_{0.05}$ test showed that $\mathrm{AK}$ was significantly different between $0-20$ and 20-40 cm, 0-20 and 40-60 cm soil depth but no significant difference was found with other soil depth as shown in table 16.

Table 16: $\mathrm{LSD}_{0.05}$ for Available phosphorus (kg/ha) at different altitudes

\begin{tabular}{llccc}
\hline Factors & $\begin{array}{c}\text { Paris } \\
\text { compared }\end{array}$ & $\begin{array}{c}\text { Mean } \\
\text { difference }\end{array}$ & $\begin{array}{c}\text { Standard } \\
\text { error }\end{array}$ & Significance \\
\hline AK & 3450 and & $523.60 *$ & 138.87 & 0.00 \\
& $3650 \mathrm{~m}$ & & & \\
3450 and & 722.50 & 138.87 & 0.00 \\
& $3850 \mathrm{~m}$ & & & \\
3650 and & 198.90 & 138.87 & 0.17 \\
$3850 \mathrm{~m}$ & & & \\
\hline
\end{tabular}

*denotes the mean difference at $\mathrm{p} \leq 0.05$ 


\section{Conclusion}

Sandy loam and loamy sand are dominant soil texture found in the study area. Basic nature of soil was found in the study area. Soil properties like TN, AK and AP were found significant different. Nutrient status was high at top soil $(0-20 \mathrm{~cm})$. The soil nutrient $(\mathrm{N}, \mathrm{P}, \mathrm{K})$ status was good in the study area.

Further research on biophysical and ecological aspect of rangeland in upper Mustang is necessary to manage it properly.

\section{References}

Awasthi, K. D. 2004. Land Use Change Effect on Soil Degradation, Carbon and Nutrient Stocks and Greenhouse Gas Emission in Mountain Watersheds. Ph.D. Thesis, Agricultural University of Norway, Norway.

Bandel, A. B. R. and Meisinger, J. J. 2000. Basic Principles of Soil Fertility I: plant nutrients. Maryland cooperative extension. University of Maryland, Maryland, USA.

Bremner. J. M. and Mulvaney, C. S. 1986. Nitrogen total. Methods of soil analysis, Chemical and microbiological properties. ASA, SSSA, Madison, Wisconsin, 595-624.
Kunwar, P. B. 2003. People-wildlife Conflict in the Upper Mustang of Annapurna Conservation Area. M.Sc. Thesis, Tribhuvan University, Institute of Forestry, Pokhara, Nepal.

Management Operational Plan (MOP) 2009. Conservation Area Management Committee, Lomangthang. National Trust for Nature Conservation-Annapurna Conservation Area Project, Nepal.

National Research Council. 1993. Soil and Water Quality: An Agenda for Agriculture. National Academy Press, Washington DC, USA.

Olsen, S. R. and Somers, L. E. 1982. Phosphorus. P. Methods of soil analysis. Chemical and microbiological properties. ASA, SSSA, Madison, Wisconsin, 403-430.

Truelsen, O. M. and Landsby, P. 2001. Application of the Nutrient Balance Concept to the Traditional Subsistence Farming System in the Middle hills of Nepal. M.Sc. Thesis, University of Royal Veterinary and Agriculture, Denmark.

Thakali, S. 1994. Regenerating Tradition: Tourism and Cultural Invention in Nepal. M.A. Thesis, Roehampton Institute, University Survey, U.K. 